月三年九十二治明

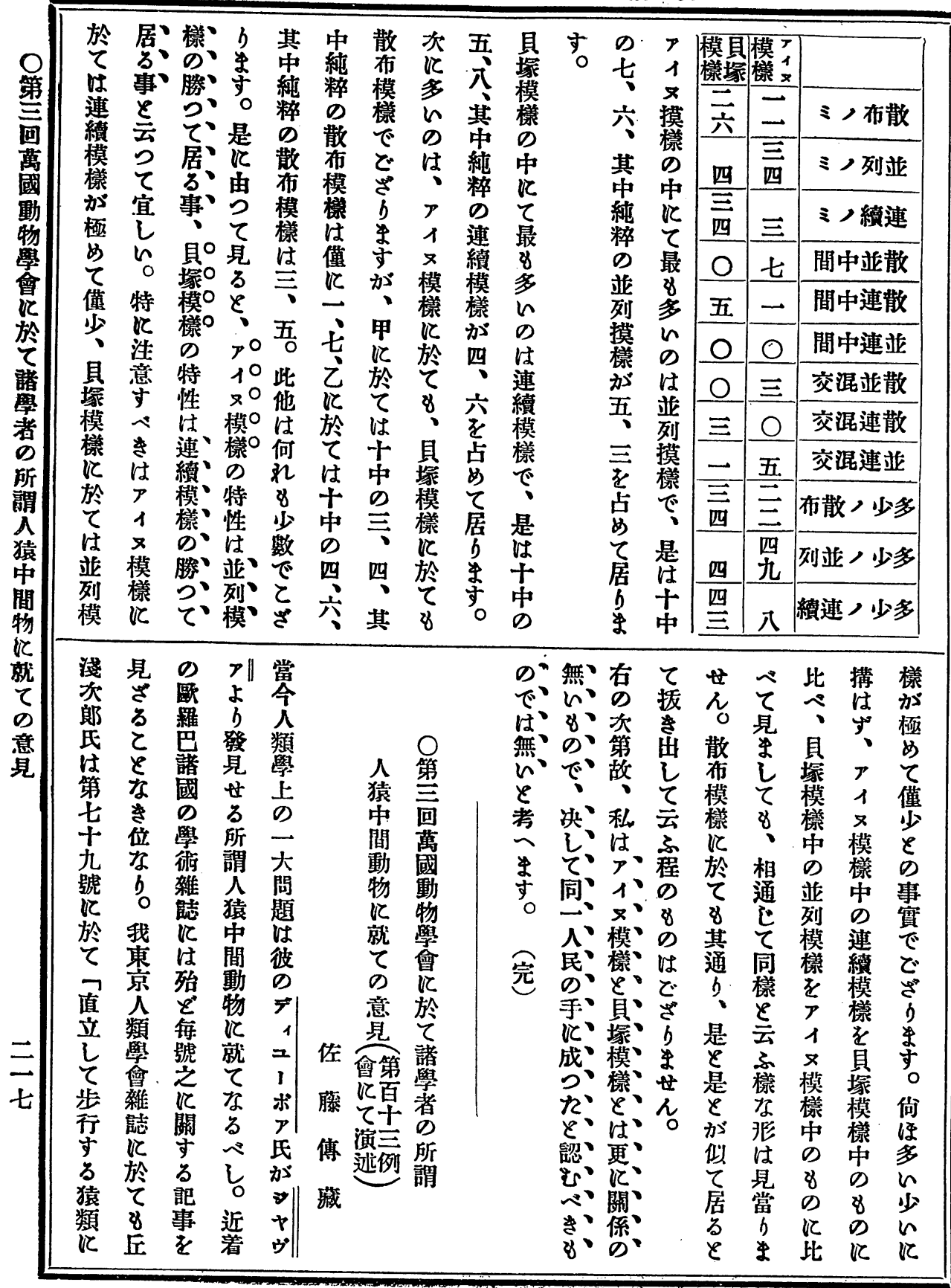




\begin{tabular}{|c|c|c|c|c|c|c|c|c|c|c|c|c|c|c|c|c|c|}
\hline 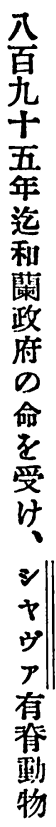 & 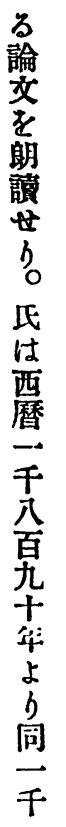 & 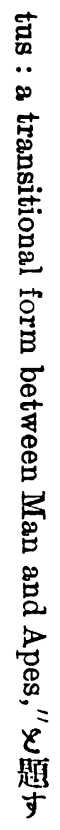 & 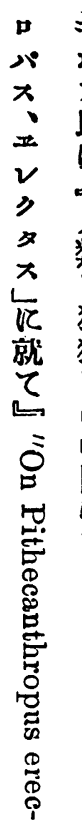 & 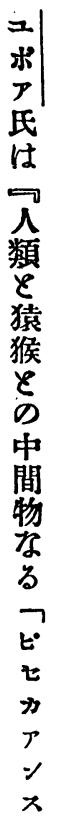 & 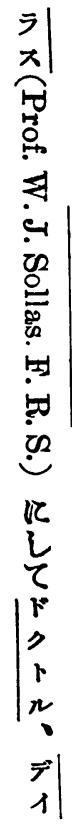 & 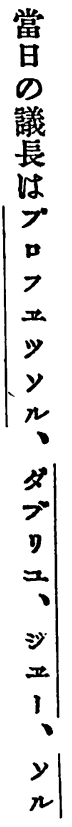 & $\begin{array}{l}\text { 左 } \\
\text { r } \\
\text { 報 } \\
\text { 告 } \\
\text { 艺 } \\
\text { ん } \\
\varepsilon \\
\text { す }\end{array}$ & 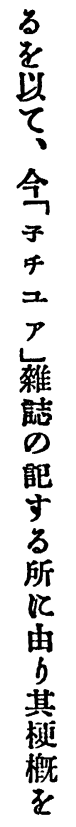 & 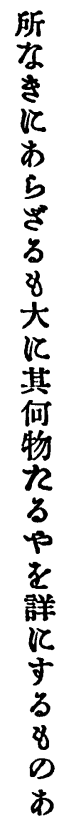 & 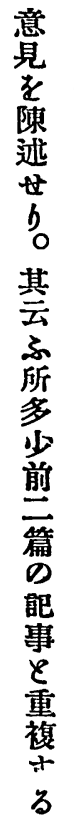 & 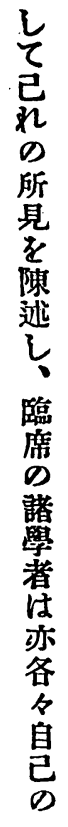 & 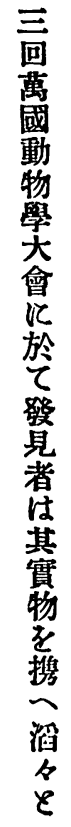 & 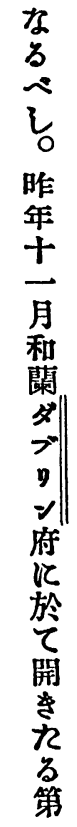 & 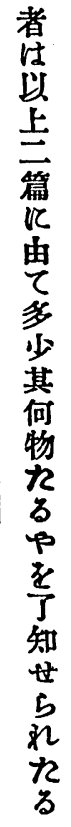 & 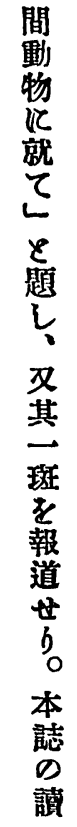 & 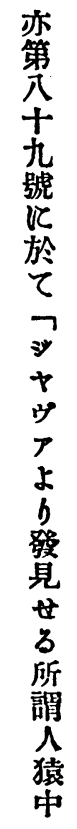 & 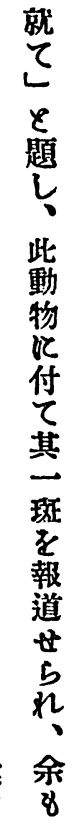 \\
\hline 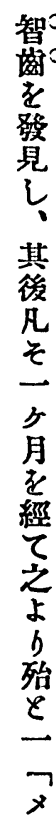 & 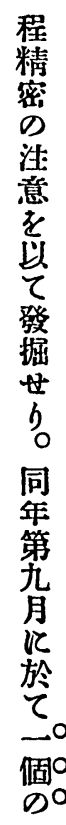 & 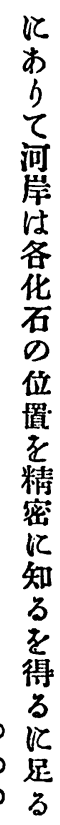 & 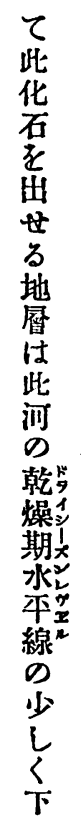 & 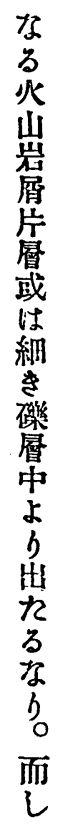 & 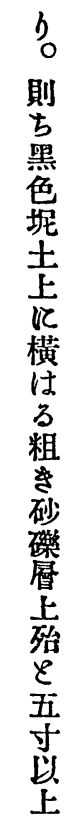 & 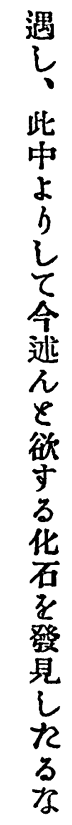 & 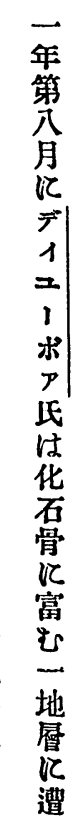 & 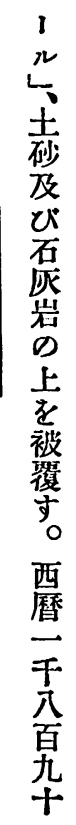 & 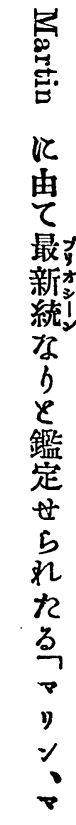 & 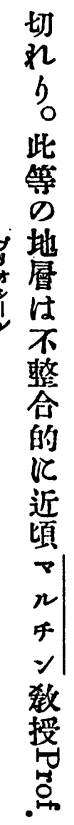 & 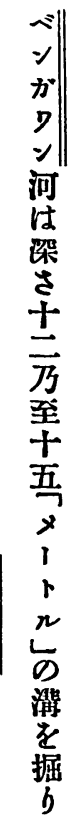 & 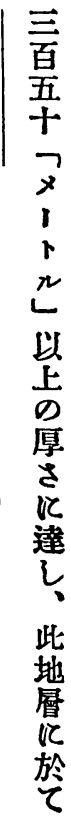 & 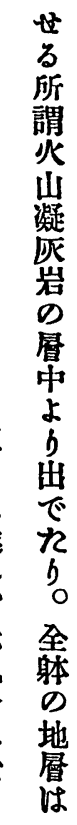 & 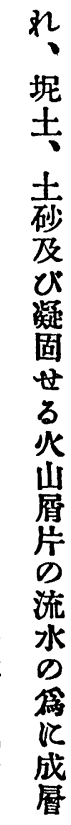 & 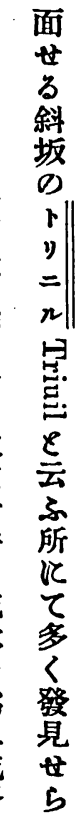 & 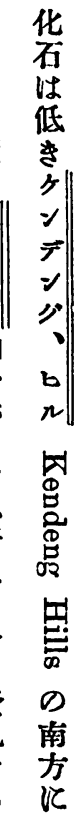 & 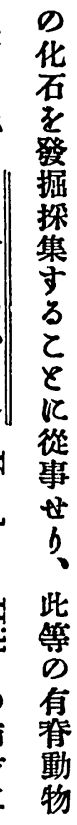 \\
\hline
\end{tabular}




\section{月三年九十二治 明}

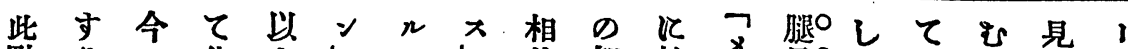

點る—化上しスし 件 智 於

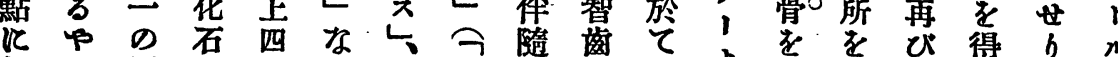

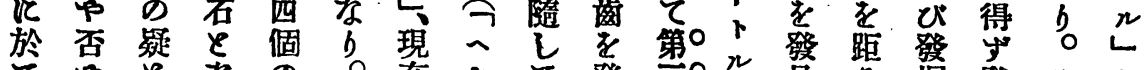

$\tau$ ○

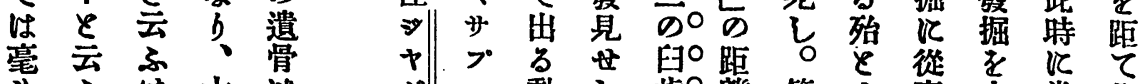

8 名性大

咨と 以 腿 凡

をと骨と

存尔四の動

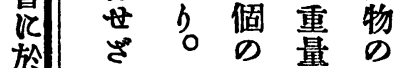

於 b

諸方》石現賅

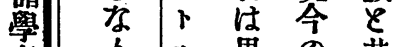

者 毛

所 何 そ) て

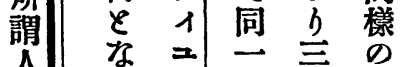

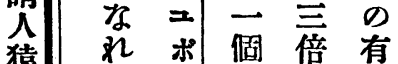

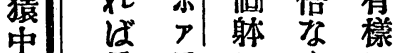

間 氏

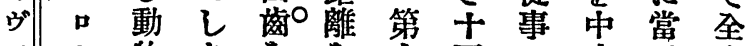

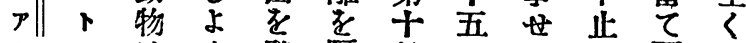

物

は屬 0 於

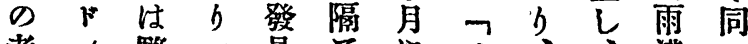

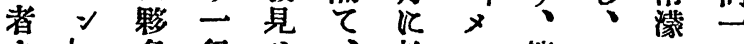

よし多年世、於、第一定の

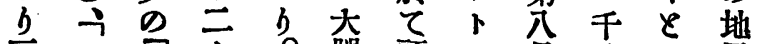

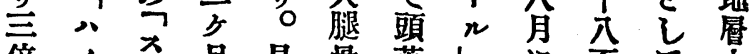

倍1

程 $テ$ 後比骨の於旮連よ

兵さ ト

な鹿告な 氏 見方 頭年開蓋。

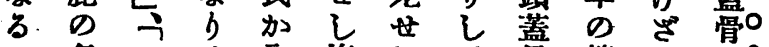

$\neg$ 各七 $と$ 初㷪して骨第 b す。

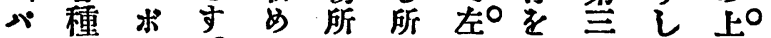

ン な゚

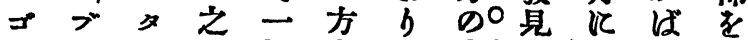

ทパ マと 個向三大如於已 發

就

て

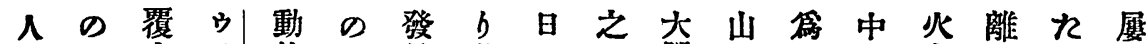

滰

見 と

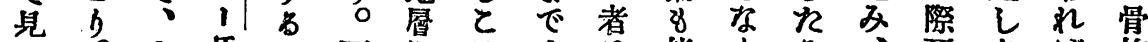

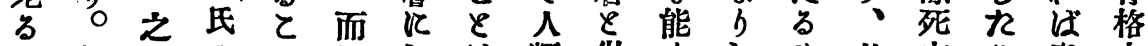

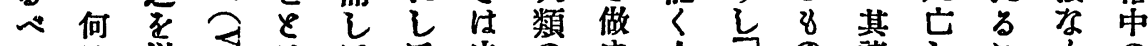
か $\varepsilon$ E

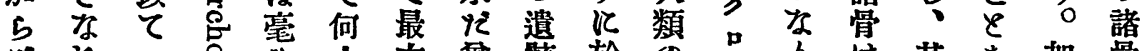

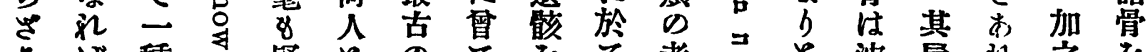
るば 種 さ疑 と

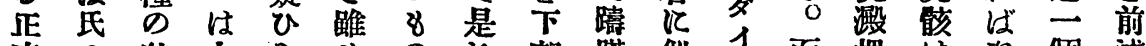

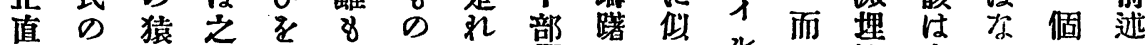

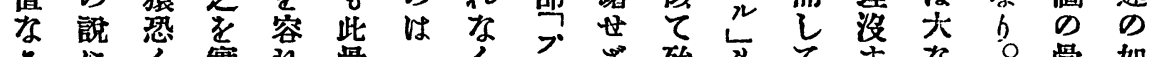

二 荥

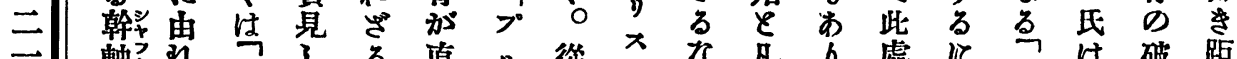

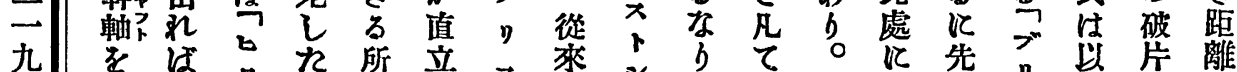

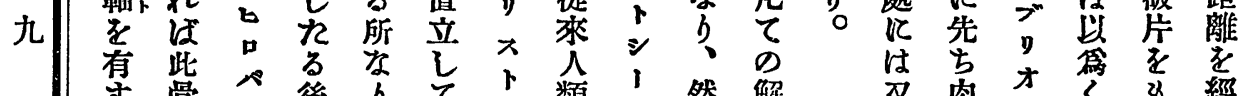
寸骨 $テ$ 後 b年

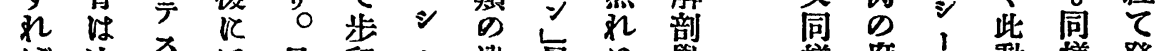

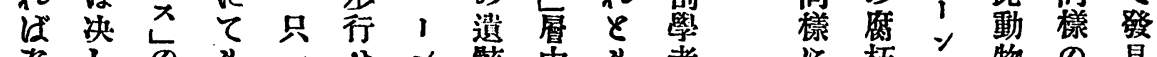
小しの \&

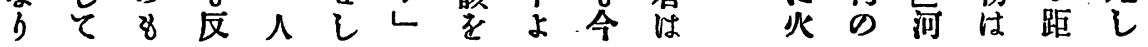


號拾二百第䀩雑會學類人京果

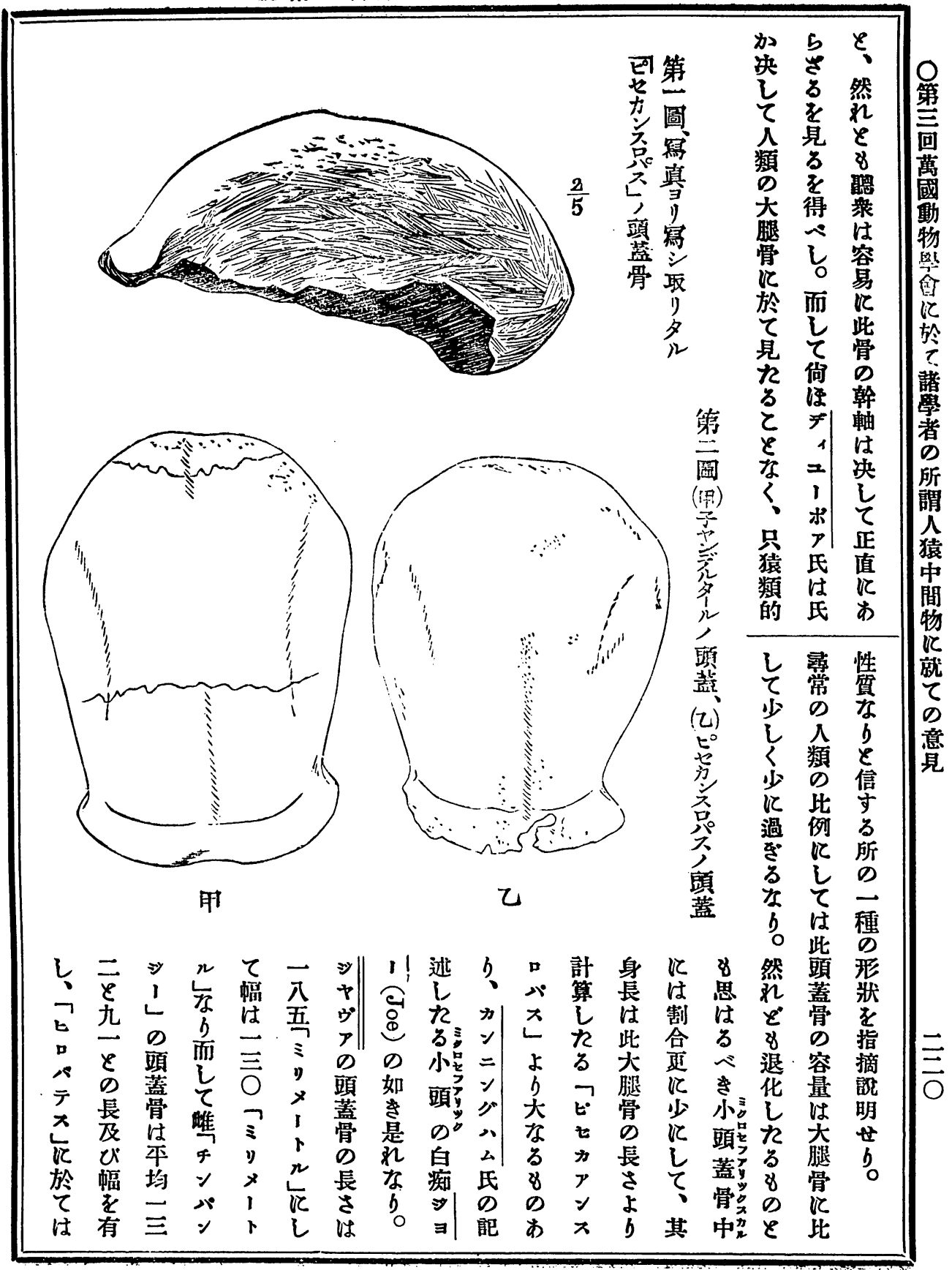




\section{月三年九十二治明}

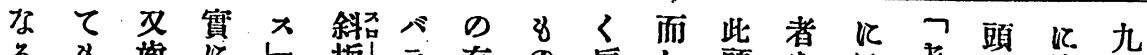

○|る 種

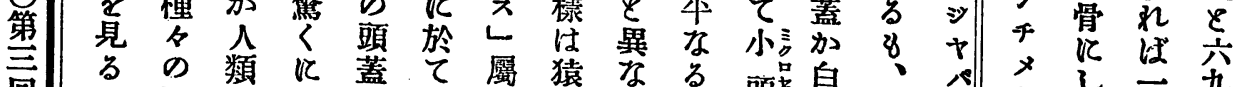

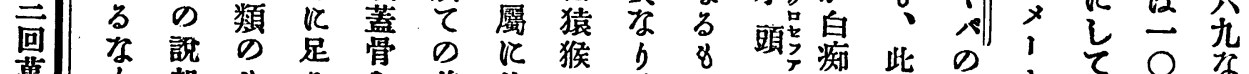
萬 り 起 8 る

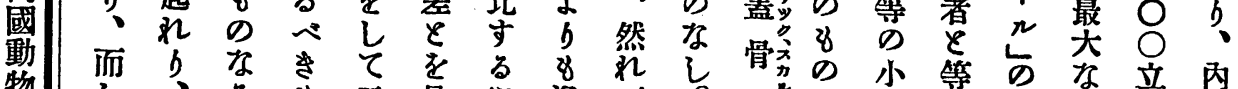
物し? る

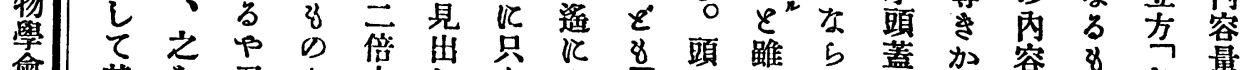

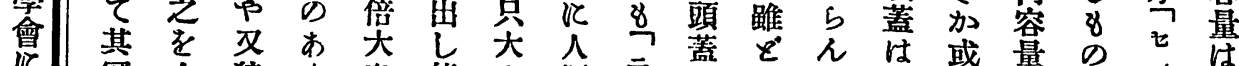

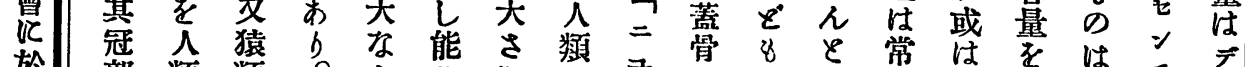

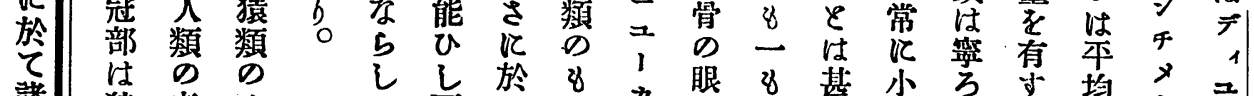

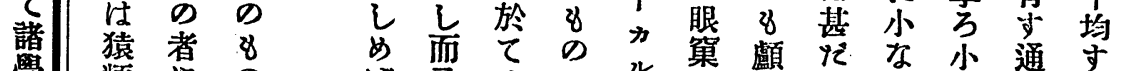

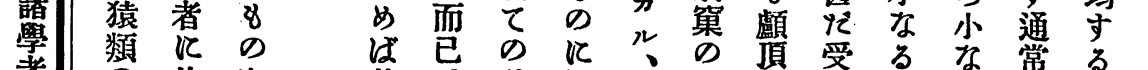

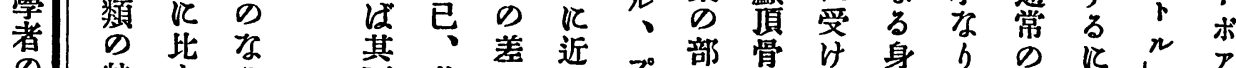
の 特卞る 兩若

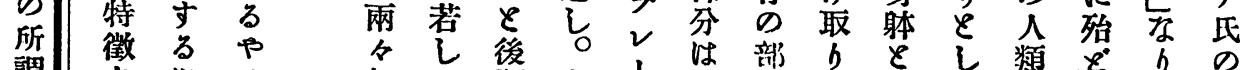

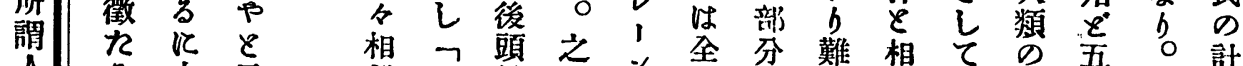

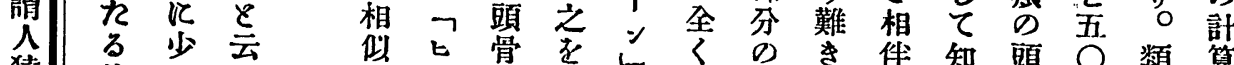
猿此之公知 $\bigcirc$ 類算

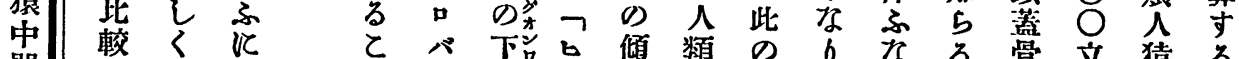

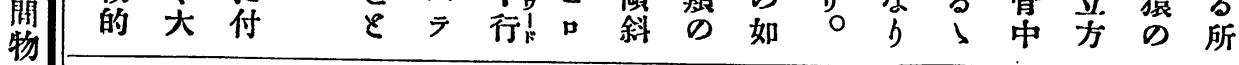

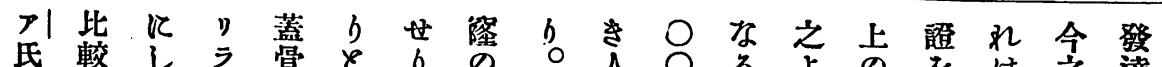
て 柱 的 て

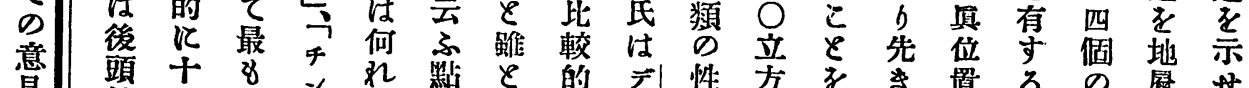

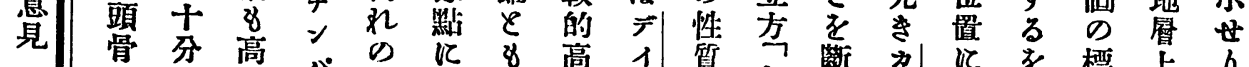
の に 等 頸乙 の 且澾、1 の

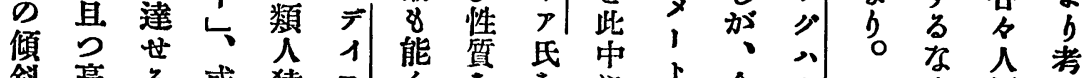
斜高 る 或 猿 多 こ 少を ロ

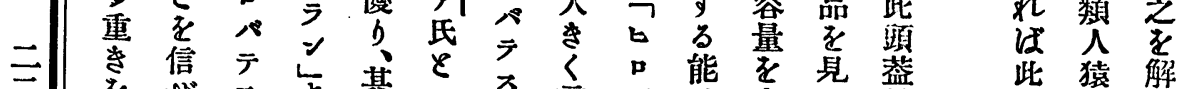
三 を せ ス よ 其

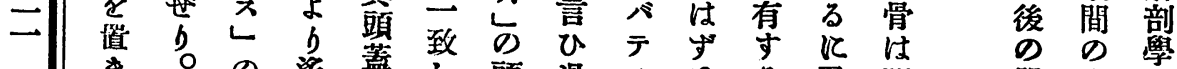

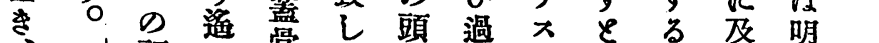

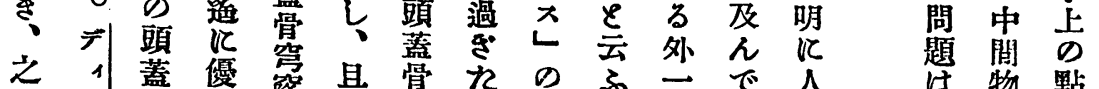

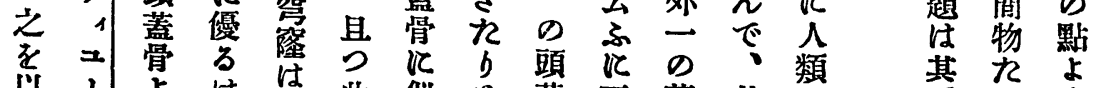

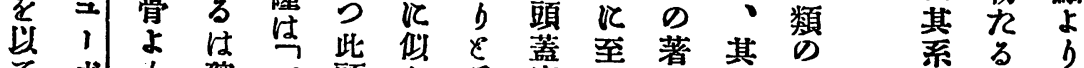

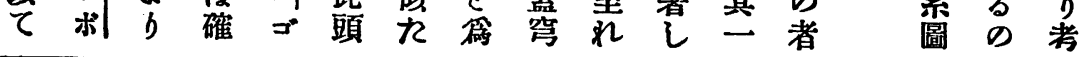


㨿拾二百第誌雑會學類人京東

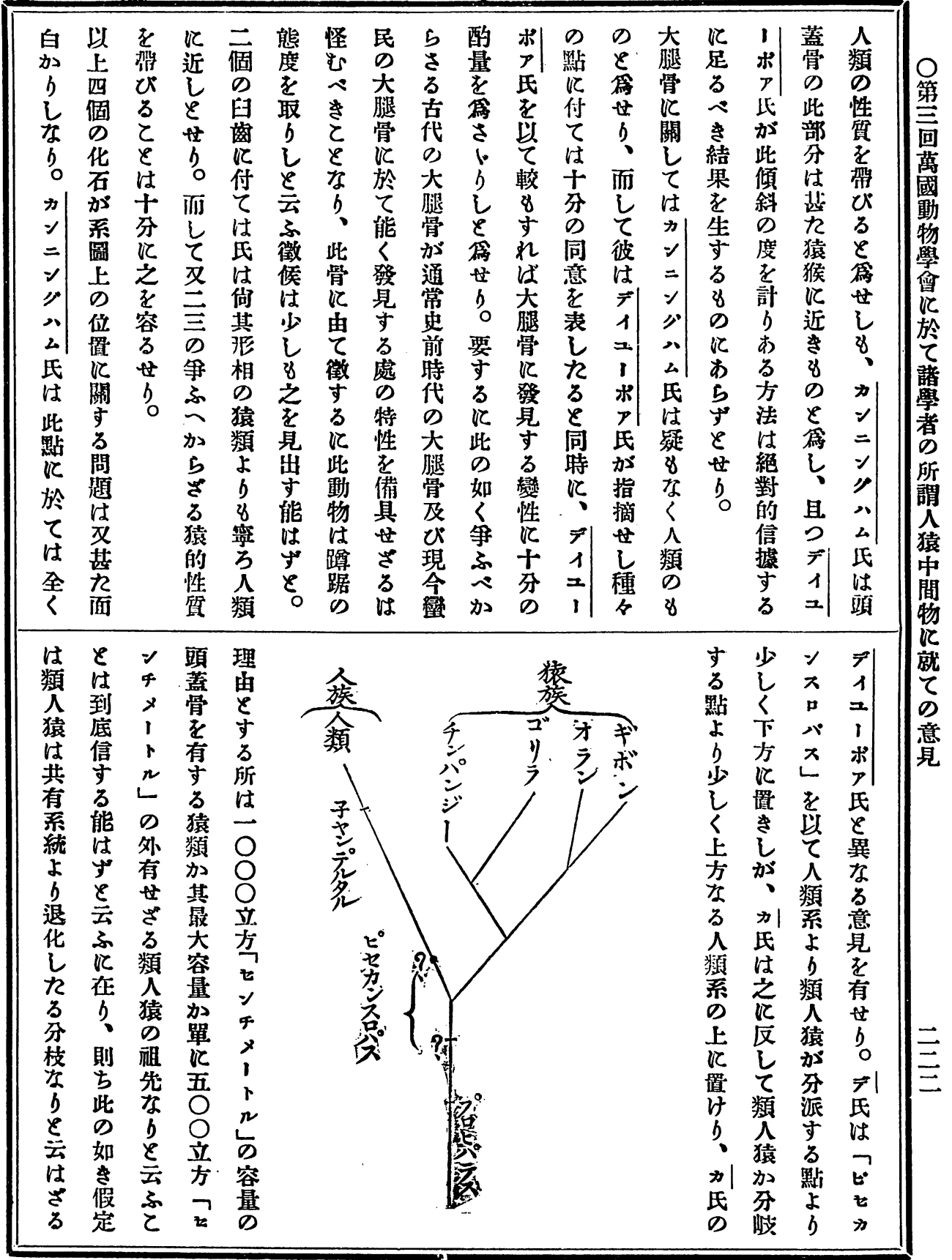




\section{月三年九十三治 明}

$\bigcirc$

あ の 類の果人只人な

、化

且 号 猿定認

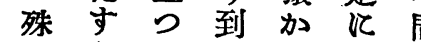

にる 日底分就䡮

蕉

阈

二 江く能岐

且當右注せ虬

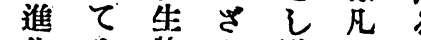

物

化p 物

學

會

曾 た 䯕

乙䐉學な篎

$\begin{array}{lll}\text { 凡 } & 3 & \text { ぶ } \\ \text { デ } & \text { 云 } & \text { を }\end{array}$

中 的

或類学實

氏

当䈣を方它

於 8 其管云方

乙人

の大る ふ㯰 致

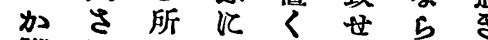

䊆

慆江於

者

の 於 由

ᄂ 2

ह

से

容てれ机

所

解

量增 は

加风之加方

諨 瓷

猿

中

閶

物

就

そ

๖ 岁览乳

前 傾勤

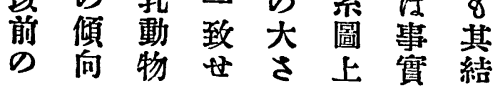

\section{楎}

下 論|プし

得

पू

る

な

b

$\varepsilon$

份

䨋

氏

の

锌

は

E

の

㮌

v

H

r

知

†

分其實 の 定著 す 與 $\mid 70$ 性 b

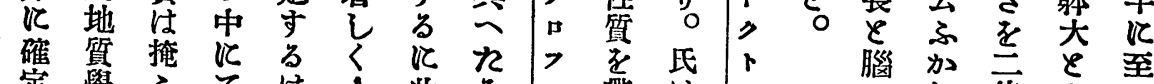
定學 心

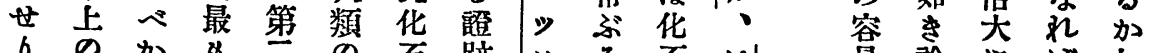
万少 と 時 5 猿 $の$ 性 は

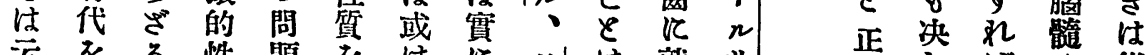

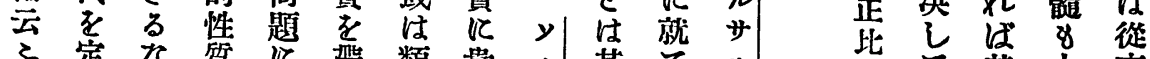

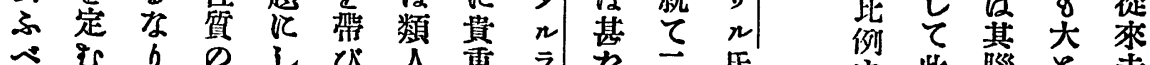

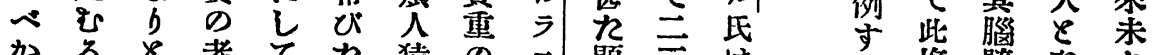

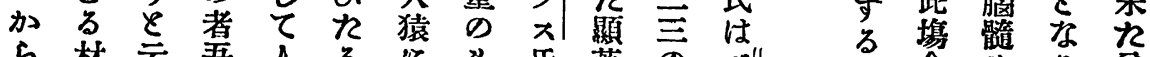
ら 㭝云 吾人 る

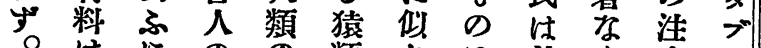
然夥

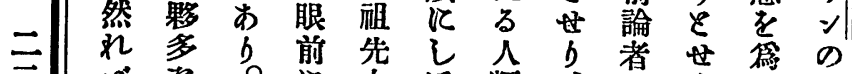

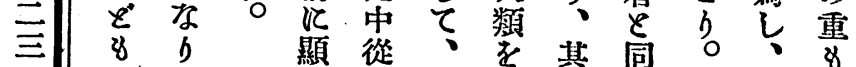

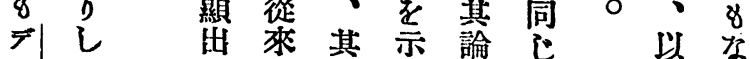

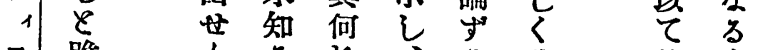

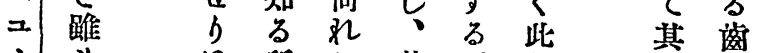

l 8 \& 所加萑所化公科

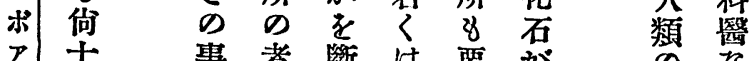

と 化等 加

角 己 故聞

称

决 心 其 告

乙 加大娄

て 5 む

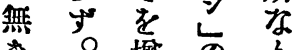
き 0 坦 の と 身妿身 を躰す 躰或 り成を大身 
躆拾二百第㮩雜會學類人京東

\begin{tabular}{|c|c|c|c|c|c|c|c|c|c|c|c|c|c|c|c|c|c|}
\hline & & & 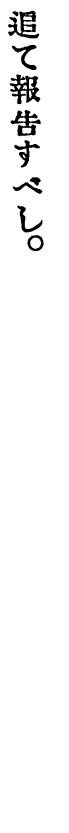 & 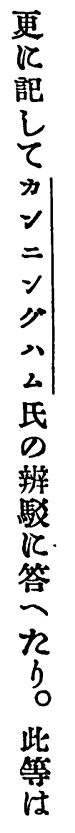 & 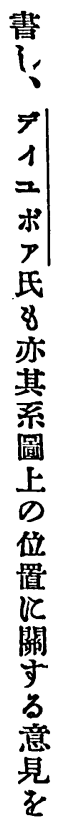 & 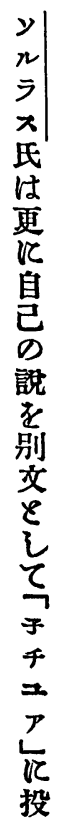 & $\begin{array}{l}00 \\
\text { के } \\
5 \\
y \\
0\end{array}$ & 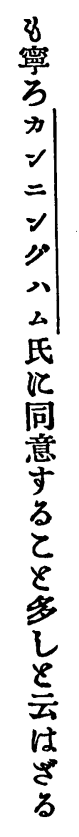 & 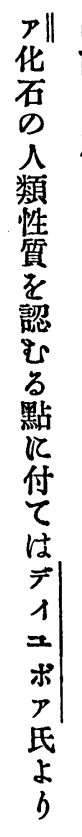 & 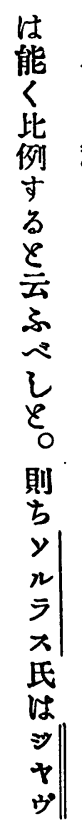 & 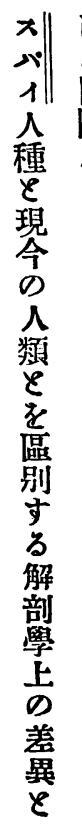 & 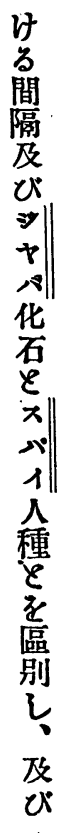 & 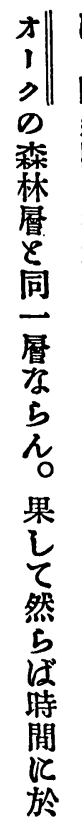 & 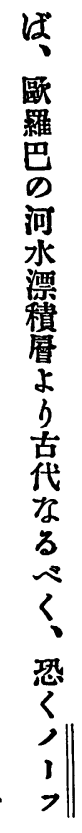 & 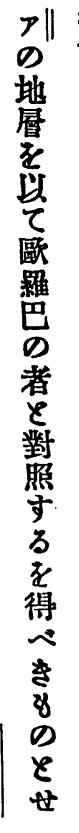 & 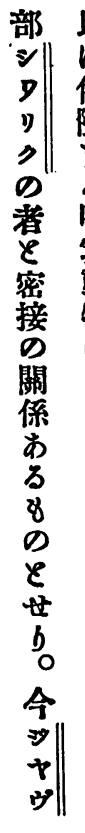 & 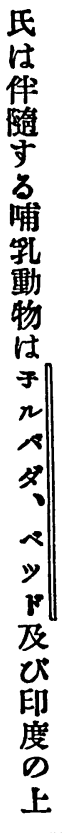 \\
\hline 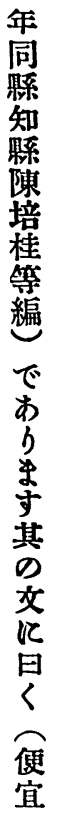 & 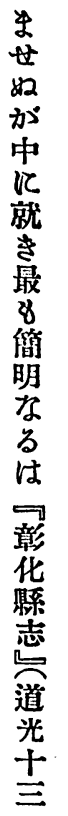 & 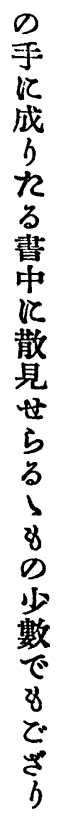 & 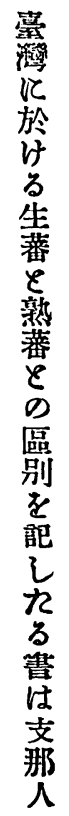 & 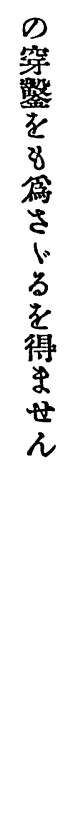 & 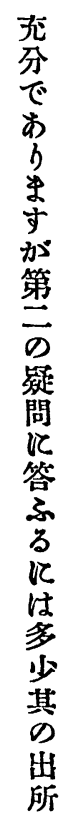 & 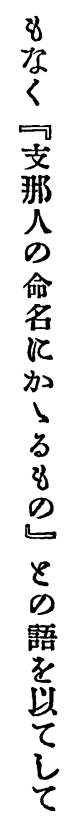 & 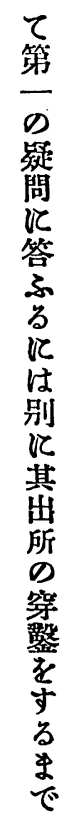 & 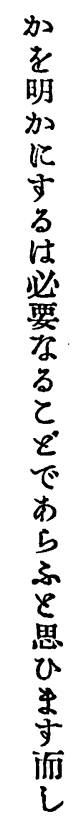 & 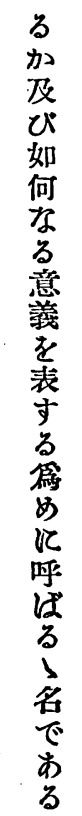 & 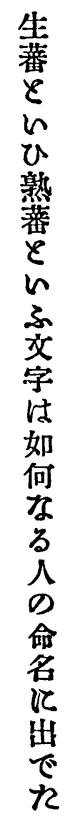 & 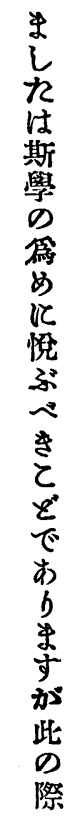 & 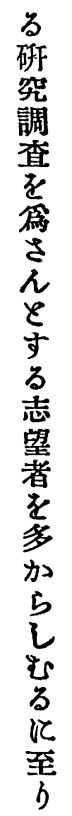 & 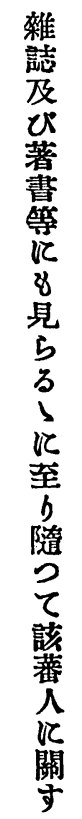 & 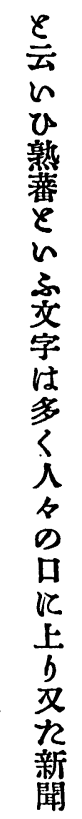 & 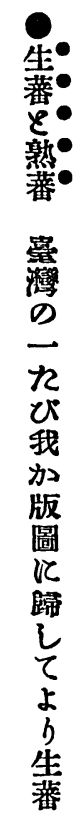 & $\begin{array}{l}\text { 在 } \\
\text { 蛮 } \\
\text { 伊 } \\
\text { 能 } \\
\text { 嘉 }\end{array}$ & 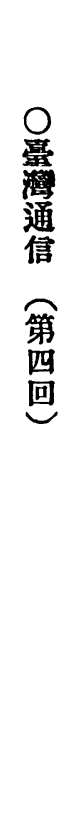 \\
\hline
\end{tabular}

